Atos de Pesquisa em Educação - ISSN 1809-0354

Blumenau, v.14, n.1, p.169-192, jan./abr. 2019

DOI: http://dx.doi.org/10.7867/1809-0354.2019v14n1p169-192

\title{
POÉTICA DAS VÉRTEBRAS: UMA PESQUISA EDUCATIVA BASEADA NAS ARTES
}

\author{
POÉTICA DE LAS VÉRTEBRAS: UNA INVESTIGACIÓN EDUCATIVA BASADA \\ EN ARTES
}

POETRY OF VERTEBRATES: ARTS BASED EDUCATIONAL RESEARCH

GASPAR, Débora da Rocha debygaspar@gmail.com

Universitat de Girona

PORTABELLA, Sílvia Úbeda silvia.ubeda.portabella@gmail.com Escola Mossen Jacint Verguedar - Barcelona / España

MELENDRO, María Luisa de la Fuente subeda2@xtec.cat Escola Mossen Jacint Verdaguer - Barcelona / España

PÁEZ, María Luisa Álvarez marisaalvarezpaez@gmail.com Escola Mossen Jacint Verdaguer - Barcelona / España

RESUMO Um encontro inesperado, mais de 9000 km de distância, uma experiência docente compartilhada e um informe de pesquisa curioso são as vértebras desta experiência. Este artigo narra o encontro de mundos docentes: quatro pedagogos dos Anos Iniciais da Catalunha e uma professora de Arte brasileira, trabalhando juntas no projeto Tándem em Artes (Música) na escola Mossèn Jacint Verdaguer em Barcelona. O relato dessa experiência educativa é elaborado a partir de metodologias artísticas de pesquisa, em que o informe final, como objeto viajante, gerou novos encontros: com a Fundação Miró e mais adeptos a trabalhar por projetos na escola Mossèn Jacint Verdaguer em Barcelona.

Palavras-chave: Educação Visual e Plástica. Interdisciplinaridade. Pesquisa Educativa Baseada nas Artes (PEBA).

RESUMEN Un encuentro inesperado, mas de $9000 \mathrm{Km}$ de distancia, una experiencia docente compartida, y un informe de investigación curioso són las vértebras de esta experiencia. Este articulo narra el encuentro de dos mundos docentes: maestros de Primaria en Cataluña y una profesora de Arte brasileña, trabajando juntas en el proyecto Tándem en Arte (Música) en la escuela Mossèn Jacint Verdaguer en Barcelona. El relato de esa experiencia educativa es hecho a partir de metodologías artísticas de investigación, en que el informe final, como objeto viajante, ha generado nuevos encuentros: con la Fundación Miró y más adeptos a trabajar por proyectos en la escuela Mossèn Jacint Verdaguer en Barcelona.

Palabras clave: Educación Visual y Plástica. Interdisciplinaridad. Investigación Educativa Basada en las Artes (IEBA). 
ABSTRACT An unexpected encounter, more than $9000 \mathrm{Km}$ away, a shared teaching experience, and a curious research report are the vertebrae of this experience. This article narrates the meeting of two teaching worlds: Primary teachers in Catalonia and a Brazilian art teacher, working together in the Tandem project in Art (Music) at the school Mossèn Jacint Verdaguer in Barcelona. The story of that educational experience is made from artistic research methodologies, in which the final report, as a traveling object, has generated new encounters: the Miró Foundation and more followers to work for projects at the Mossèn Jacint Verdaguer School in Barcelona.

Keywords: Arts-based Educational Research. Interdisciplinarity. Visual and Plastic Education.

\section{INTRODUÇÃO}

O presente artigo apresenta o relato de um dos campos da pesquisa "IEBA na escola: arte como centro de narrativas investigativas", um projeto que reuniu experiências em diferentes níveis e cenários educativos. No Colégio de Aplicação da Universidade Federal de Santa Catarina (UFSC), instituição com a qual estava vinculado, abrangeu como objetos de estudo: um projeto educativo focado em uma narrativa carnavalesca no quarto ano dos Anos Iniciais; uma pesquisa PIBID desenvolvida com uma estudante do Ensino Médio sobre a representação da transexualidade no cinema; e a experiência de aprender sobre as metodologias artísticas de pesquisa com o grupo de estudos destinado a professores da Educação Básica vinculados ao projeto de extensão Arte na Escola.

Outro cenário em que a pesquisa foi aplicada é a Escola Pública de Educação Infantil e Anos Iniciais Mossèn Jacint Verdaguer em Barcelona - Espanha. Tal pesquisa buscou verificar como ocorre o processo de construção do conhecimento em Arte na escola, a partir das metodologias artísticas de pesquisa (Investigación Educativa Basada en las Artes - IEBA). Neste artigo, apresentamos o processo de elaboração do informe final da pesquisa no contexto da Escola Mossèn Jacint Verdaguer em Barcelona, um relato de experiência de pesquisa educativa baseada nas metodologias artísticas de pesquisa com duplo destino: de um lado mostrar no Brasil as similitudes e diferenças das práticas pedagógicas desenvolvidas no contexto espanhol; do outro, devolver aos professores da escola em Barcelona a visão da professora de Arte e pesquisadora brasileira sobre o que verificou em seu 
estágio de observação participativa no projeto Tándem de Música 2014/2015 que tratava dos Animais Vertebrados.

\section{PESQUISA EDUCATIVA BASEADA NAS ARTES: AS VÉRTEBRAS}

Nós, seres humanos, somos organismos contadores de histórias. Vivemos vidas relatadas, seja individual, seja socialmente; e partindo desse pressuposto se constitui a perspectiva narrativa de pesquisa em educação (CONNELLY; CLANDININ, 1995). A pesquisa narrativa, então, seria o estudo da forma em que os seres humanos experimentam o mundo.

Tomando referências da pesquisa narrativa, cria-se outra perspectiva - a Pesquisa Baseada nas Artes (PBA) - que busca articular as narrativas visuais e de outras linguagens artísticas além da verbal, tanto na coleta de dados como na formulação de problemas e construção do informe final de pesquisa. Assim, as Pesquisas Baseadas nas Artes (PBA) apresentam-se como uma metodologia adequada para compreender como a Arte, na prática docente, articulando conhecimentos e linguagens de outras áreas, pode gerar novos discursos nas práticas educativas e de pesquisa. Nessa perspectiva, a fundamentação teórica desta pesquisa transita pela Investigação Narrativa (CONELLY; CLAUDININ, 1995) com enfoque nas metodologias artísticas de pesquisa (BARONE; EISNER, 2012).

Roldán e Viadel (2012) consideram que as metodologias artísticas de pesquisa consistem em uma forma de fazer pesquisa em Ciências Sociais e Humanas, trabalhando em analogia à criação artística, na qual o conhecimento das diferentes áreas artísticas é usado, tanto no que diz respeito à abordagem e definição de problemas de obtenção de dados quanto na elaboração de argumentos, conclusões, demonstração e apresentação dos resultados finais.

Entretanto, as metodologias artísticas de pesquisa apresentam também potencial no âmbito educativo, pois é um meio de relacionar diferentes formas de narrativas, o que pode vir a ser uma excelente estratégia para se trabalhar os múltiplos letramentos na escola, aspecto ressaltado por autores como Fernando Hernández (2007). Na perspectiva do PEBA (Pesquisa Educativa Baseada nas Artes), o informe da pesquisa deve atingir a diferentes públicos e, por se apropriar de linguagens artísticas, permite ultrapassar as barreiras acadêmicas, chegando a 
uma audiência mais ampla e diversificada. Por essa razão, esta pesquisa não está centrada apenas nas disciplinas artísticas, vai além, ao trabalhar com professores de outras áreas do conhecimento, como os "maestros" de Barcelona.

Portanto, a coleta dos dados apresentada foi realizada em uma escola pública de Barcelona (Espanha), MOSSĖN JACINT VERDAGUER, localizada no bairro de Poble Séc. Esta escola trabalha com Educação Infantil e Anos Iniciais. Também participa do Programa "Escuelas tándem", desde 2011, com ênfase na Música, em parceria com o Conservatório Municipal de Música de Barcelona (CMMB). Este Programa consiste em um projeto educativo no qual a escola seleciona um eixo central para se especializar. Segundo o site da Fundação Catalunya Caixa, órgão financiador que colabora com o departamento de Ensino, esta especialização ou tándem (música, ciências, matemáticas, inglês, audiovisuais, etc.) é uma parceria entre escolas e instituições de referência na área específica selecionada pela escola.

\section{ANIMAIS VERTEBRADOS}

Em um encontro fortuito, em uma lagoa da llha de Santa Catarina (Brasil), comendo "panallets"1 feitos de castanha do Pará e regadas por conversações em Espanhol, Silvia contou sua experiência como professora em uma escola pública no bairro de Poble Séc em Barcelona. Ela trabalhava com os primeiros anos em um projeto cujo eixo central era a Arte, mais especificamente, a Música. O projeto Tándem em Música causou curiosidade na professora de Arte brasileira que tecia esta conversa castelhana, pois como explicou Silvia, neste projeto a escola escolhia uma área ou disciplina para ser o eixo norteador do currículo escolar e na sua instituição haviam selecionado a Música. Assim, meses depois desse encontro, a professora de Arte brasileira embarcou em um avião rumo a Barcelona para conhecer de perto essa experiência em que a Arte (Música) era o centro do currículo escolar.

\footnotetext{
1 São doces típicos das regiões espanholas de Catalunha e Baleares, uma receita de meados do século XVII a base de amêndoas e cobertura de pinoli. Esses doces são consumidos no dia primeiro de novembro, Dia de Todos os Santos, festividade conhecida como "Castanhada".
} 
No primeiro dia na escola, a professora de Arte foi apresentada aos demais professores catalães numa reunião do planejamento do Projeto Tándem. Nesse encontro, Silvia solicitou uma participação mais ativa da brasileira, não apenas como observadora, mas atuando junto às crianças para desenvolver a construção plástica dos animais vertebrados que estariam estudando naquele ano: tubarão, cachorro, águia, salamandra e jacaré. O desafio foi aceito e mais do que observar como trabalhavam, que era o objetivo inicial da pesquisa, vivenciou-se uma experiência docente ao participar ativamente do projeto com estudantes e professores na construção de animais tridimensionais.

Convém ressaltar que, no currículo espanhol, a área de Arte incorpora as disciplinas de Educação Visual e Plástica e a Música. As aulas de Música devem ser ministradas por um professor com formação específica em Música, entretanto, as aulas de Artes Visuais são as próprias professoras regentes que devem ministrá-las, já as demais linguagens artísticas não fazem parte do currículo obrigatório. Por causa da falta de formação na área, as docentes da escola Jacint Verdaguer tinham dificuldades em concretizar suas propostas no que se refere aos aspectos técnicos da produção plástica, assim a presença de uma professora de Artes Visuais com formação específica lhes ajudaria a colocar em prática seus planejamentos.

Uma preocupação e cuidado que as professores tiveram foi a de oportunizar um espaço adequado para o trabalho estético. Silvia havia conhecido a realidade do Colégio de Aplicação da UFSC no Brasil, em que as aulas de Arte são ministradas nas diferentes linguagens (Teatro, Artes Visuais e Música) por professores de formação nessas áreas, com um grupo reduzido de estudantes (média de 13 alunos) e contando com salas de aula específicas, como os atelieres de Artes Visuais, preparados para desenvolver os projetos estéticos com diferentes técnicas. Entretanto, a escola Mossèn Jacint Verdaguer, na Espanha, não tinha um espaço semelhante, tendo sido usado o átrio e a própria sala de aula para desenvolver os trabalhos estéticos. O trabalho com grupos reduzidos foi mais fácil de gerenciar, pois se adotaram as seguintes dinâmicas: sair das salas com pequenos grupos de alunos para trabalhar no átrio a vista de toda a escola ou trabalhar com pequenos grupos dentro da sala de aula, enquanto a professora regente ministrava outros conteúdos aos demais estudantes. 
Durante um mês, entre dezembro de 2014 e janeiro de 2015, trabalhou-se com quatro turmas, duas de primeiro e duas de segundo ano de Primaria (Anos Iniciais), cerca de 80 crianças no total, quatro professores regentes (Silvia, Maria Luiza, Marisa e Albert). Também se obteve ajuda do professor de Educação Especial e uma pequena participação em uma aula da professora de Espanhol. Também foi estabelecido contato nas reuniões com o professor de Música e de Educação Física, mas não houve qualquer intervenção ou observação em suas aulas.

Este foi o contexto com o qual se deparou a professora brasileira ao entrar no edifício histórico que abriga a escola Mossèn Jacint Verdaguer, prédio construído para a imprensa na Exposição Universal ${ }^{2}$ de 1929 , e que atualmente abriga este centro educativo que atende a Educação Infantil e Anos Iniciais num sistema de ensino em tempo integral.
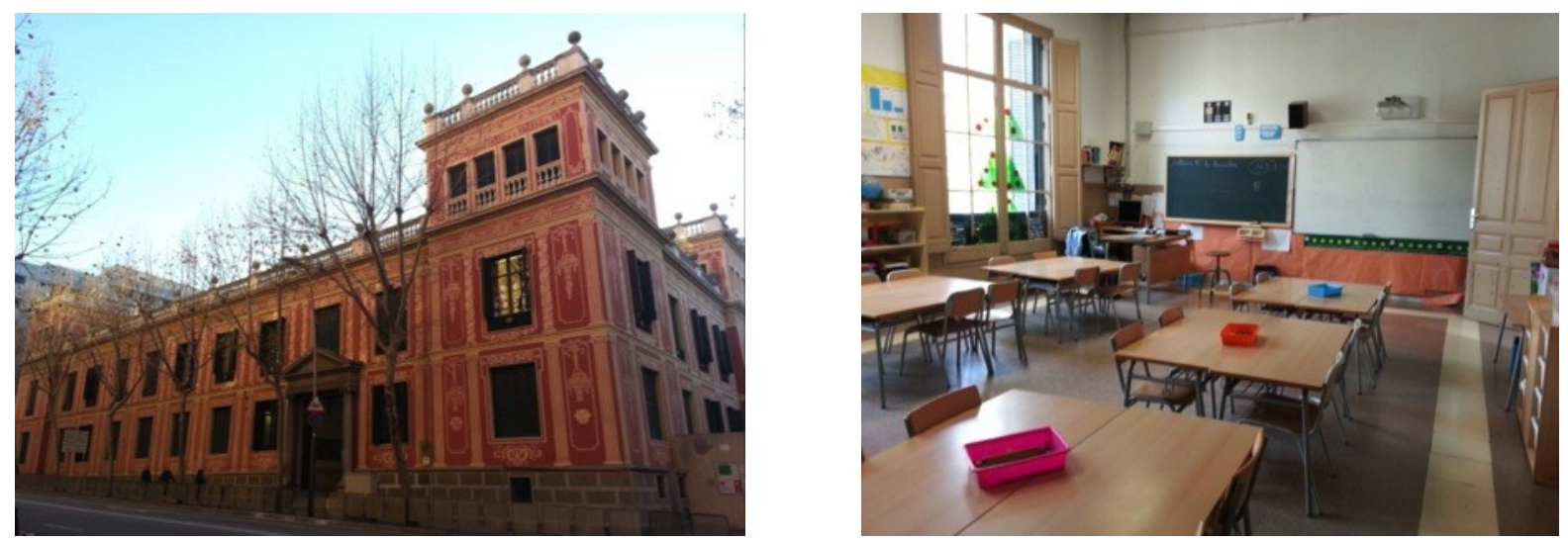

Fig. 1 e 2 - Escola Mossèn Jacint Verdaguer, Sants - Montjuïc, em Barcelona/Espanha.

A escola está localizada em Pobla Sèc, um bairro popular, historicamente conhecido por abrigar imigrantes, inicialmente espanhóis, oriundos de zonas mais pobres da Espanha e, hoje, de diferentes países, destacando-se os de origem árabe, chinesa e latino-americana. Percebeu-se que quase não havia crianças de famílias espanholas, a maioria era de origem árabe, alguns chineses, dentre outras nacionalidades. Havia uma menina de família brasileira.

\footnotetext{
2 A Exposição Internacional de Barcelona aconteceu de 20 de maio de 1929 a 15 de janeiro de 1930 nas proximidades da montanha de Montjuïc. Foi um evento importante para o desenvolvimento urbanístico daquela zona da cidade de Barcelona.
} 


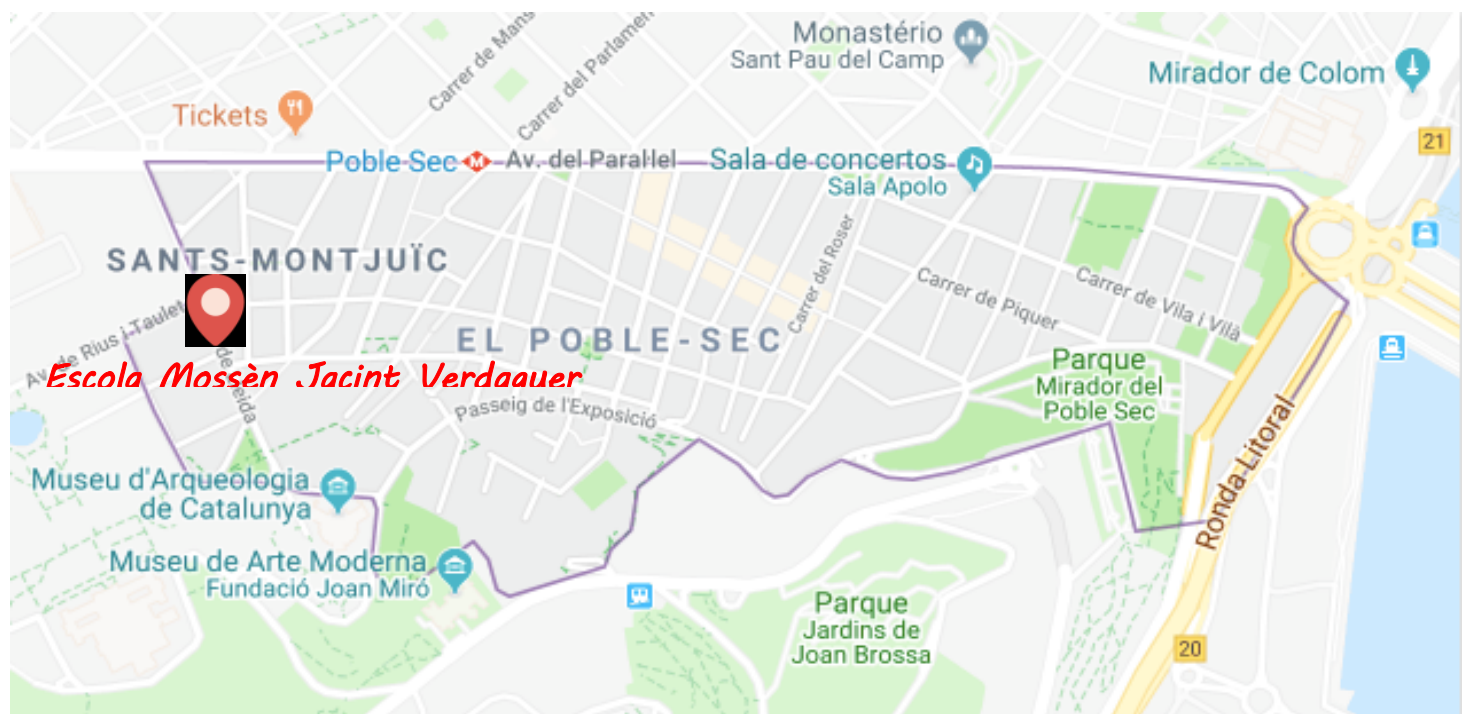

Fig. 3 - 17 Localização da Escola Mossèn Jacint Verdaguer, Barcelona/Espanha.

Silvia explicou que em Poble Séc havia mais quatro escolas públicas que atendiam a Educação Infantil e Anos Iniciais, e ressaltou ainda que as crianças de famílias espanholas se concentravam nas mais renomadas, já as famílias árabes buscavam matricular seus filhos sempre nas mesmas escolas. Observou-se que havia muitas mães muçulmanas que pouco se comunicavam. A professora Silvia revelou ainda que muitas mães não falavam Espanhol ou Catalão (idioma também oficial nas escolas de Barcelona). Nas reuniões de pais, eram geralmente os homens que se comunicavam, mas que em muitas ocasiões os professores e dirigentes da escola pediam a eles que traduzissem às mulheres o que estava sendo comentado.

Constatou-se que a maioria das crianças convivia com pelo menos quatro idiomas diferentes: o Espanhol em uma disciplina curricular; o Inglês ensinado como Língua Estrangeira; o Catalão como oficial da escola; além dos idiomas que falavam com seus familiares em casa. Entre as crianças, no contexto escolar, o idioma usado era o Catalão, pelo que se pode observar nos momentos do recreio. Como a professora brasileira não dominava o Catalão e se dirigia às crianças em Espanhol, pode-se constatar que elas tinham bastante domínio deste idioma também, pois respondiam, sem hesitar, em Espanhol.

A primeira intervenção da professora de Arte com os estudantes foi buscar ampliar seus repertórios visuais, abordando variadas representações artísticas de animais de diversos períodos históricos e estilos estéticos, uma abordagem 
iconológica da arte. Para estruturar essa aula utilizou uma apresentação no prezi, adaptada de uma anterior, produzida para os seus alunos dos primeiros anos do Ensino Fundamental do Colégio de Aplicação da UFSC. Nesta apresentação, foi reconstruído no aplicativo uma das tantas representações de touro que o artista espanhol, Pablo Picasso, fez durante sua vida artística. Convém ressaltar que em Barcelona está situado um dos museus destinados a trajetória deste artista, uma vez que realizou parte de sua formação nesta cidade. Dessa forma, Picasso é um importante ícone da Arte na Catalunha, juntamente a Salvador Dalí, Joan Miró e Tàpies.

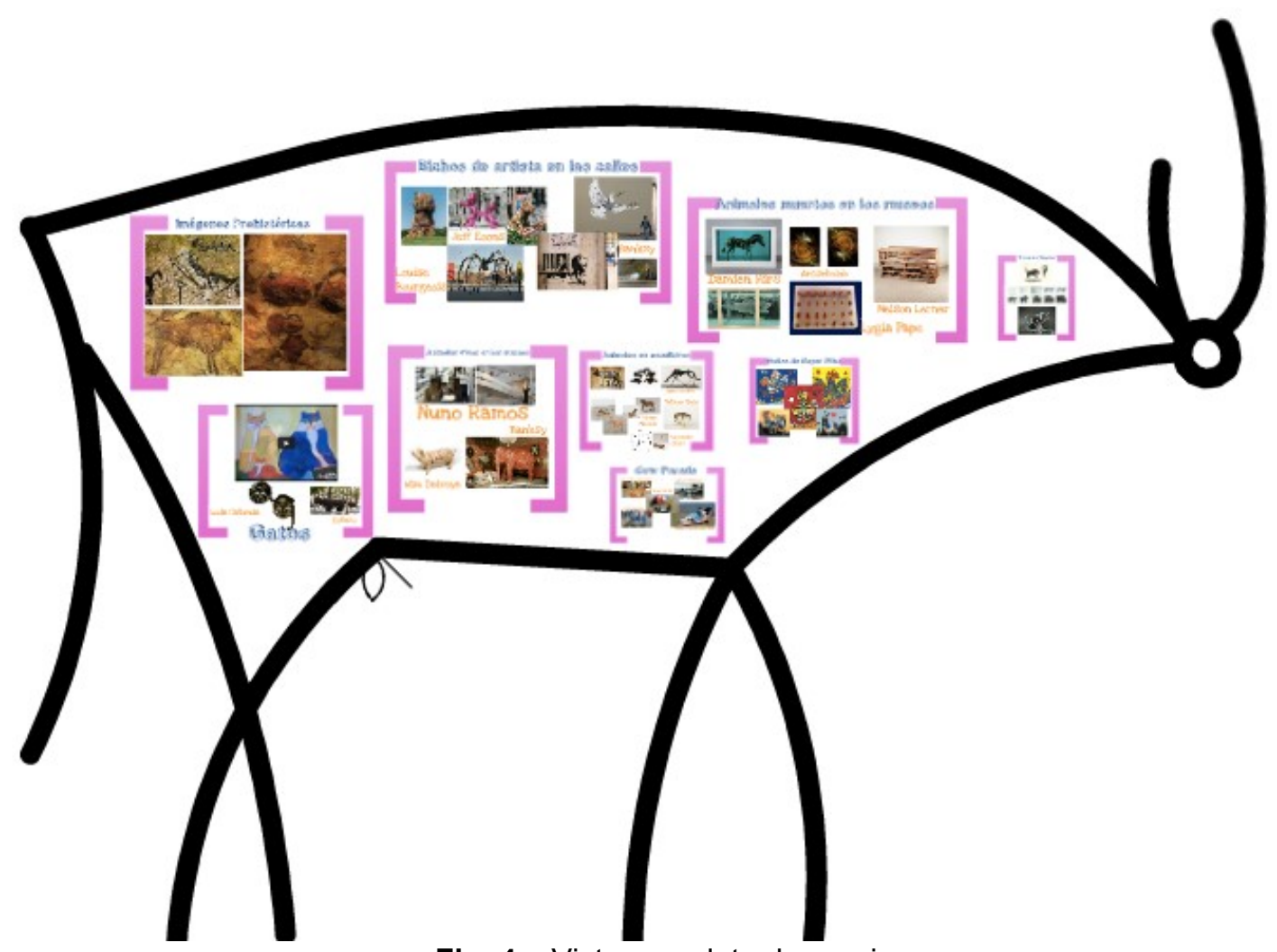

Fig. 4 - Vista completa do prezi

Para sistematizar as mais variadas formas de representação e até mesmo de apropriação da imagem dos animais na arte, fez-se uma "classificação" a partir dos seguintes paradigmas: imagens pré-históricas (inscrições rupestres dos bizontes nas cavernas); animais em esculturas (figuras de madeira dos índios Guarani de Biguaçú; obras de Giacometti; Efrain Almeida; Tatiana Blass e Alexander Calder); galos de Mayer Filho (artista de Florianópolis); touros de Picasso (imagens e vídeos dos touros desenhados e pintados por Picasso); gatos (obras de Leda Catunda, 
Botero e Aldemir Martins); animais vivos em museus (obras de Nuno Ramos; Win Delvoye e Banksy); bichos de artistas nas ruas (Louise Bourgoeis; Jeff Koons; Banksy); Cow Parade.

Neste prezi, apresentaram-se alguns artistas brasileiros às crianças em Barcelona, tais como o modernista Aldemir Martins e os contemporâneos Nuno Ramos, Leda Catunda, Efrain Almeida e Tatiana Blass. Entre os artistas catarinenses, enfatizaram-se os Galos, de Mayer Filho e as intervenções da Cow Parade, em Florianópolis. As crianças logo reconheceram o Gato de Botero que fica na Rambla do Raval, bairro vizinho à escola em Barcelona. Mas foi a obra Ballon Dog, de Jeff Koons, que referenciou a construção do cachorro, animal que os estudantes do primeiro $B$, da professora Maria Luiza, iriam construir.

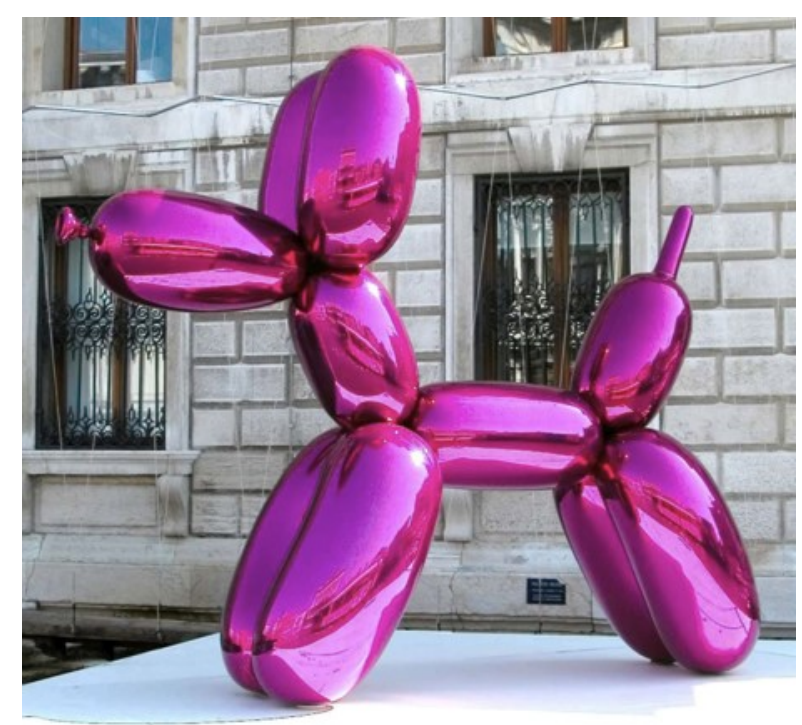

Fig. 5 - Balloon Dog, versão magenta, Jeff Koons

\section{CORPORIFICANDO AS VÉRTEBRAS}

A segunda proposição às crianças foi desafiá-las a representarem os animais que iriam estudar. Elas desenharam os cachorros, por exemplo, trazendo as referências dos bichinhos que conheciam. A professora Maria Luiza falou de seu próprio cachorrinho, conhecido por alguns de seus alunos, pois ela é moradora do bairro e costuma passear com ele pelas ruas e habitualmente encontra seus alunos fora da escola. 


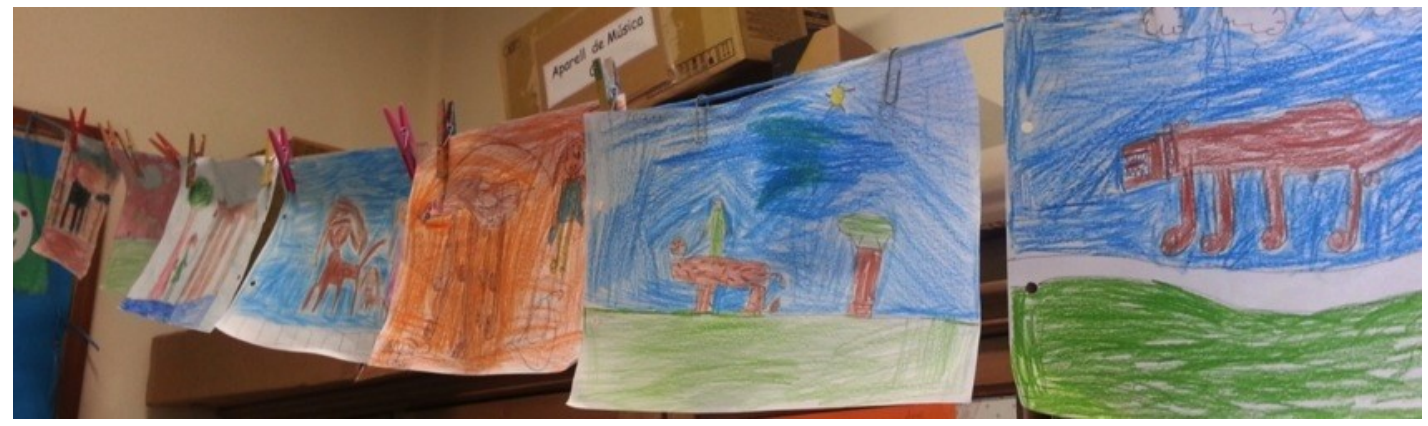

Fig. 6 - Desenhos dos alunos da turma do primeiro ano da professora Maria Luísa

A terceira proposta feita às crianças foi que elas elaborassem um projeto/ esboço que orientasse a construção desses animais em três dimensões e com os materiais disponíveis na escola, ou que eles pudessem trazer de casa. As professoras tinham disponíveis vários materiais recicláveis, tais como: caixas de papelão, caixas de ovos, garrafas pet e jornais.

Os estudantes da professora Marisa, por exemplo, para construírem o jacaré, usaram as próprias caixas que estavam disponíveis em sala de aula. No átrio da escola, um grupo de alunos selecionou as caixas de papelão para estruturarem o corpo do animal a ser representado. Após a montagem, encaparam as caixas com papel de cera verde; para representar a textura da pele do jacaré, usaram uma esponja com tinta verde mais escura. As crianças também utilizaram caixas de ovos para construírem a boca do jacaré.

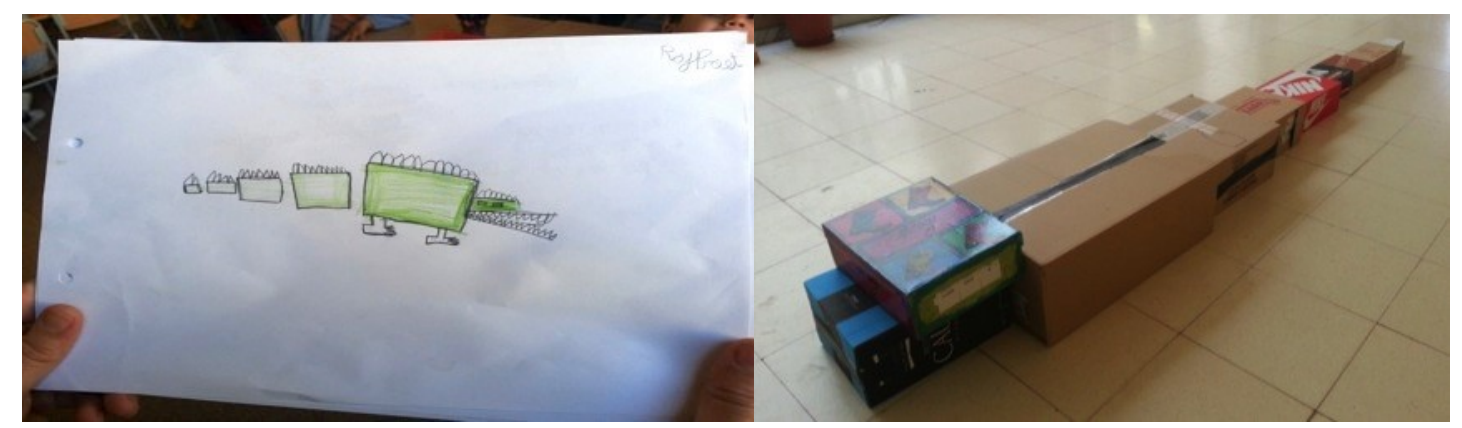

Fig. 7 - Projeto e estrutura do Jacaré

A construção estrutural do corpo do jacaré com caixas foi um elemento importante para as crianças compreenderem como os animais vertebrados são constituídos. As vértebras equilibram os animais, assim como as caixas deram 
"corpo" ao jacaré produzido pelas crianças. Essa concepção foi também muito bem assimilada pelos estudantes do primeiro ano da professora Silvia; eles, no préprojeto do tubarão, fizeram um levantamento dos materiais disponíveis que pudessem ser utilizados para a construção da estrutura do animal.

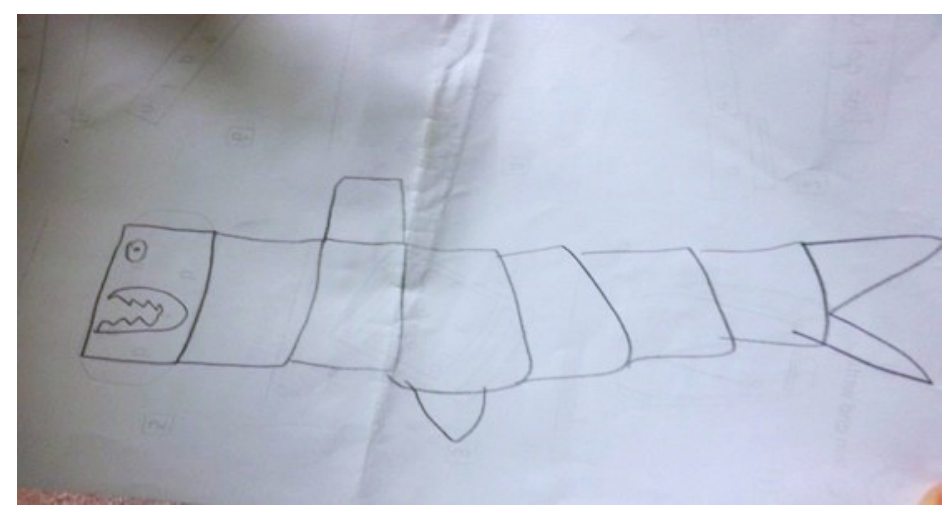

Fig. 8 - Pré-projeto de um aluno do primeiro ano da professora Sílvia.

No caso do tubarão, entretanto, quando fomos realizar a montagem da estrutura com as caixas, vimos que o encaixe necessitava de mais intervenção, então se sugeriu às crianças fazer a técnica de papietagem ${ }^{3}$ com jornal, inclusive mostraram-se exemplos e os materiais necessários para a sua execução. Como as crianças eram pequenas, a professora de arte teve que reforçar bastante a estrutura com fita adesiva, mas para que todo o processo fosse acompanhado pelos estudantes realizou essa intervenção no átrio da escola, um lugar de passagem, e onde não apenas os alunos que estavam no projeto poderiam acompanhar o trabalho, mas também crianças das demais turmas que passavam e ficavam observando sua atuação, questionavam e tentavam adivinhar os animais que iriam sair daquela montagem ainda sem forma definida.

\footnotetext{
${ }^{3}$ Técnica artesanal em que se utiliza papel recortado e cola para dar forma a uma escultura ou objeto.
} 

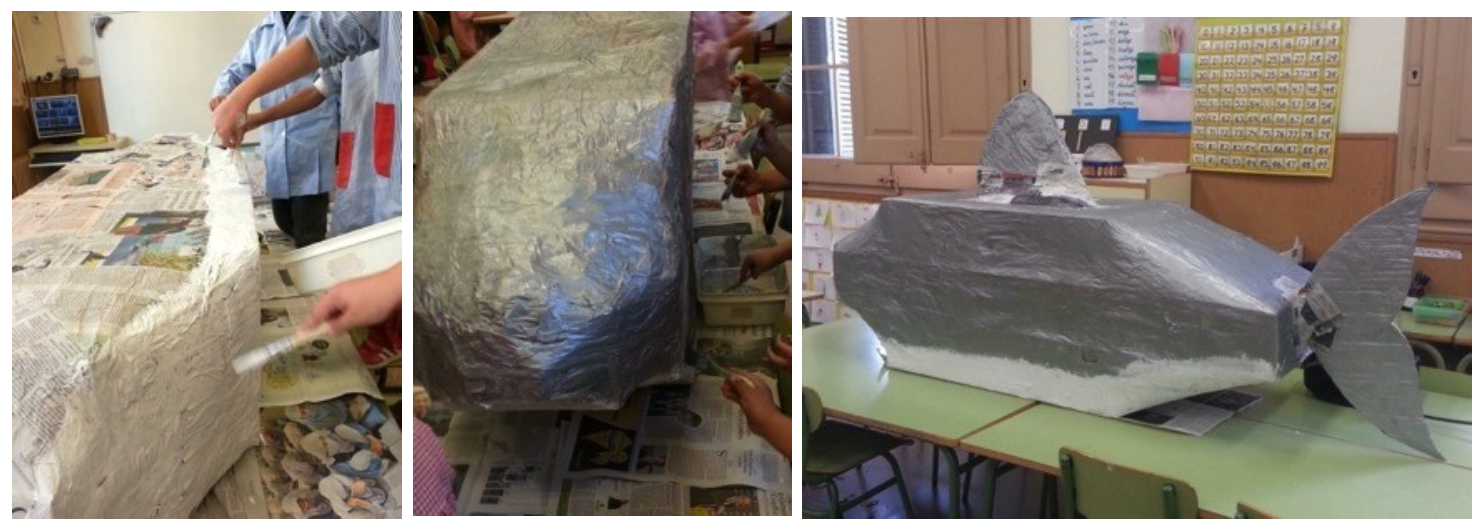

Fig. 9 - Etapas de construção do tubarão.

Para os demais animais, houve a necessidade de ir indicando possibilidades estruturais para as crianças montarem seus bichinhos, como foi com o cachorro, a salamandra e a águia. A ideia inicial dada para a águia, por exemplo, era de fazer uma pandorga gigante, pois o principal objetivo de construção desses animais tridimensionais era para atender o desejo dos professores de produzirem um musical no final do curso para uma apresentação à comunidade escolar. Nesta apresentação, as crianças iriam interpretar as canções trabalhadas pelo professor de Música e mostrar o que haviam aprendido sobre os animais vertebrados durante o ano letivo, num cenário povoado pelos animais feitos por eles. Assim, pendurar uma pipa no teatro do Centro Cívico do bairro poderia gerar uma dificuldade que os professores talvez tivessem problemas em operacionalizar, uma vez que a professora de Arte não estaria em junho para ajudá-los a montar o espetáculo.

Então, sugeriu-se construir a águia com uma estrutura de totem, esculturas realizadas em cedro por índios norte-americanos na forma de pilar ou poste que geralmente retratavam animais selvagens como aves e peixes. Tal estrutura seria rígida o bastante para ser transportada e daria conta de representar a águia. Assim, os alunos do segundo ano B montaram a estrutura com caixas de papelão, material abundante na escola, e pensaram com qual material poderiam recobrir o totem e simular a textura da pena da ave; eles então selecionaram o papel de seda nas cores negra, marrom e dourada. 


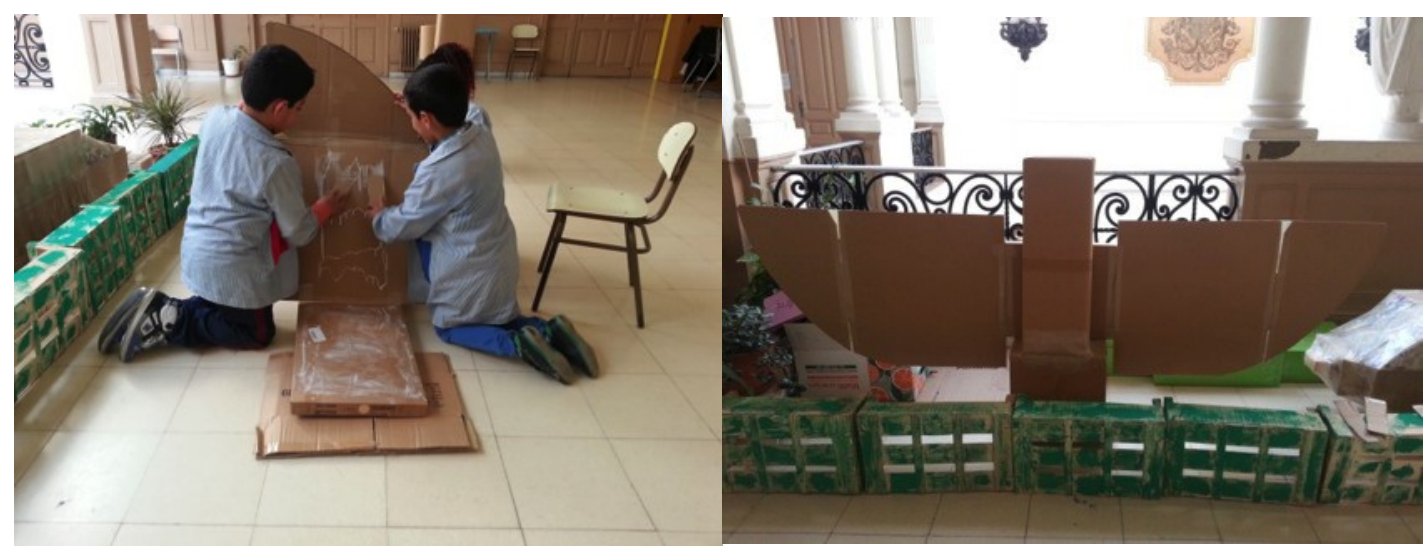

Fig. 10 - Construção da águia e sua estrutura com papelão.

Para a construção da salamandra, utilizaram-se imagens fotográficas dos animais e a proposta era projetar essas imagens sobre uma caixa de papelão aberto para contornar as linhas do animal e recortar sua forma. Sugeriu-se também que enchessem o corpo da salamandra de jornal e recobrissem de lã. Assim, enquanto a professora Marisa ministrava os conteúdos das demais disciplinas curriculares, a professora de arte trabalhava em uma das mesas com as crianças em turnos e juntos iam dando forma e textura à salamandra.

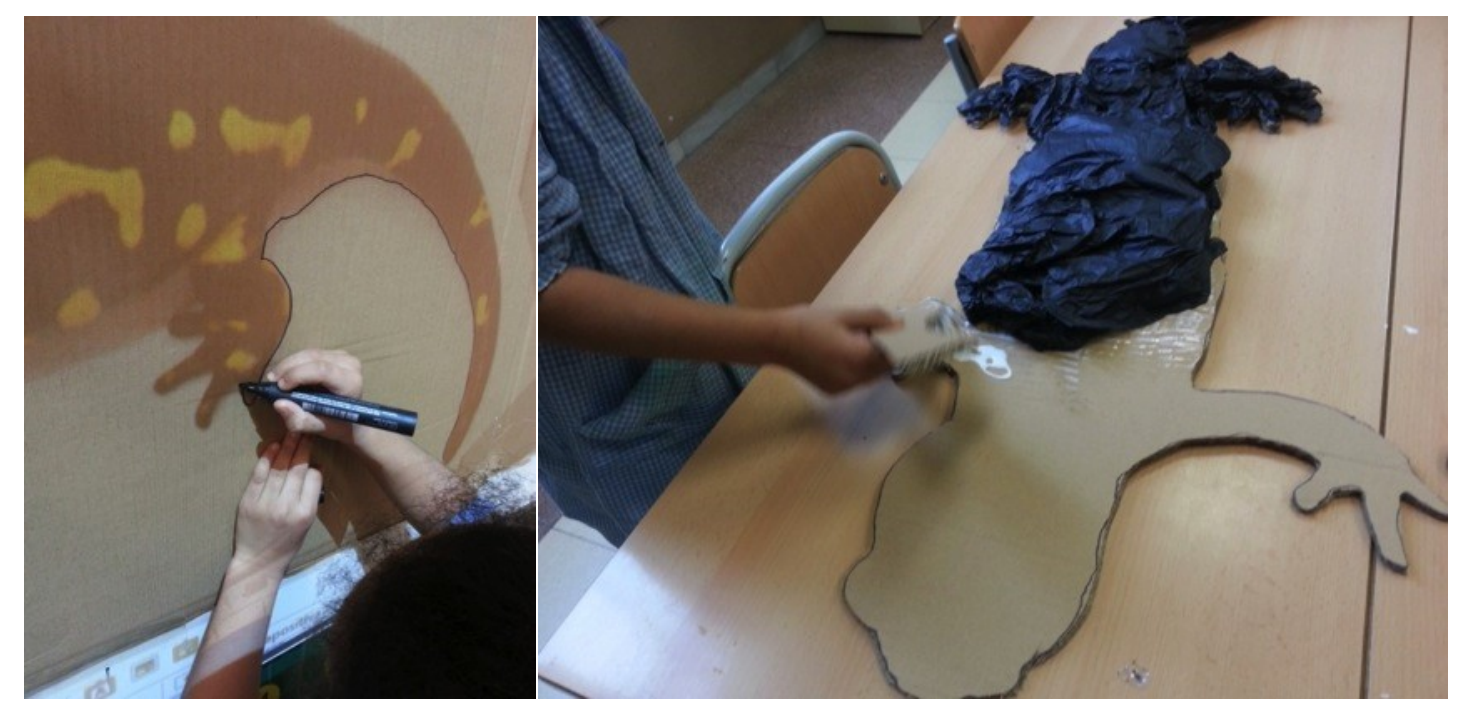

Fig. 11 - Estudantes da professora Marisa construindo a salamandra.

Mas foi na construção do cachorro, na turma de primeiro ano da professora Maria Luiza, que se observou como as intervenções interdisciplinares mais significativas podem e devem acontecer na mediação conjunta entre o professor regente e o professor de Arte. No dia anterior, as crianças haviam realizado uma saída de estudos pelo bairro, encontraram um senhor que construía cachorrinhos de 
balão, como a obra de Jeff Koons, e se lembraram da imagem mostrada para eles no prezi. Quando a professora de Arte entrou na sala, mostraram o cachorrinho de balão que haviam ganhado daquele senhor. Então, seguindo a estrutura do balão, usaram-se garrafas pet que eles haviam trazido para a escola. Enquanto montavase a estrutura do cachorro com as crianças, receberam a visita da professora Silvia, do primeiro A, para ver o trabalho que estavam realizando na turma ao lado. Assim, ao observar que a professora brasileira tentava relacionar o posicionamento das garrafas ao conjunto ósseo do animal, Silvia espontaneamente iniciou uma mediação com as crianças em que relacionava a montagem da "escultura" do cachorro com o esqueleto do animal, explicando as características biológicas dos animais vertebrados enquanto um grupo de crianças ia dando forma ao cãozinho/objeto. Essa intervenção de Silvia foi extremante significativa para as crianças, elas conseguiram compreender como era complexa e importante a estrutura óssea nos animais vertebrados simulando-a na montagem com as garrafas pet, equilibrando-as e pensando em articulações entre as partes.

Foram as crianças que pensaram na lã como um material possível para representar o pêlo do cachorro, e também fizeram uma votação para selecionar a cor que iriam dar ao cachorrinho. Foi interessante esta escolha, porque ao mostrar o cachorro magenta metalizado de Koons, as crianças se sentiram livres para usar uma cor que não necessariamente retrataria o animal tal como o vemos na realidade, mas assim como os artistas, eles poderiam dar asas à imaginação e propor que a escultura do cachorro fosse de uma cor "irreal". Neste momento, eles compreenderam que o que realmente estavam construindo não era um cachorro, mas a simulação, representação, presentificação do cachorro, e não o animal em si.

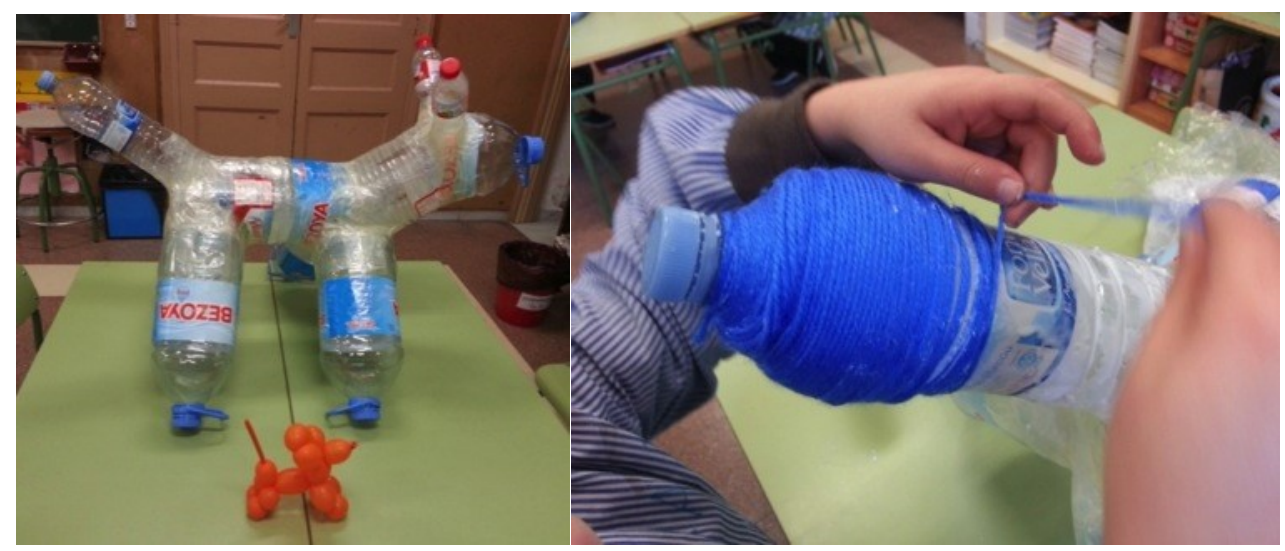


Fig. 12 - Construção do cachorro com estrutura de garrafa pet.

Este episódio foi bastante significativo, pois sem qualquer planejamento a intervenção da professora Silvia converteu a sala de aula, com pé-direito alto e janelas verticalizadas de um edifício histórico, em um ambiente de aprendizagem interdisciplinar.

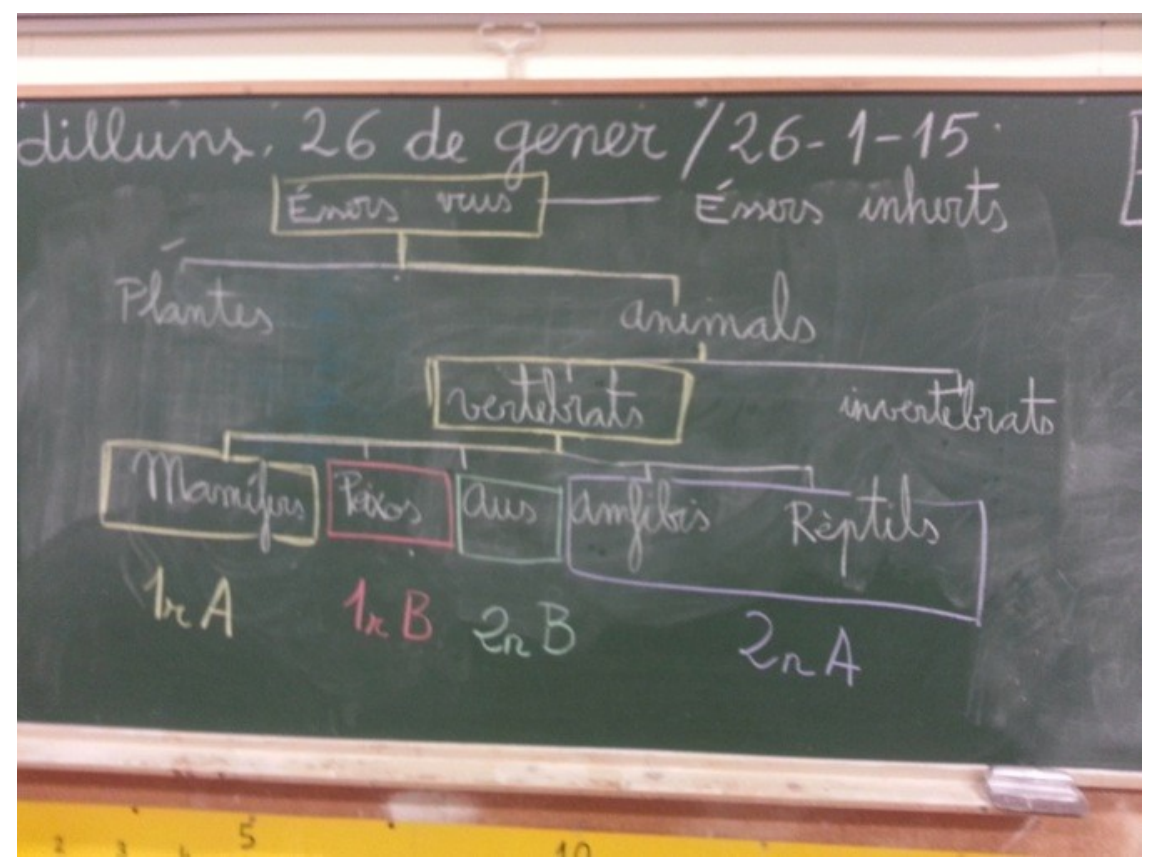

Fig.13 Foto do quadro com o esquema realizado pela professora Sílvia escrito em catalão

Devido ao curto período de tempo em Barcelona, pouco se pode transitar pelos eixos de leitura e contextualização das imagens artísticas nesse projeto, tampouco houve um maior desenvolvimento das dimensões críticas e reflexivas tão importantes para o ensino da Arte na escola. A ênfase foi dada à produção técnica dos objetos tridimensionais. Nesse aspecto, houve uma sensação de frustração ao não se poder dar continuidade à intervenção e contribuir mais com o desenvolvimento do projeto para além do papel ilustrativo das artes visuais, chegando ao nível interpretativo e narrativo, como propõe as metodologias artísticas no âmbito da pesquisa acadêmica (ROLDÁN, VIADEL, 2012). Percebeu-se que, mesmo a Música sendo escolhida como área específica do projeto Tandém e usada para a apresentação final do projeto dos Animais Vertebrados, ainda estava muito presente o caráter ilustrativo das artes. Assim, a Música era um meio representativo 
para tratar dos conteúdos curriculares de outra área do conhecimento. A disciplina de Arte, devido ao seu alto nível expressivo e representativo, geralmente é apropriada nos projetos educativos como meio de validar outros campos do conhecimento, mas a essência de suas linguagens não chega a ser explorada. Isso se dá pela complexidade nas formas de interpretação e criação dos códigos visuais, cênicos e sonoros; por serem linguagens semi-simbólicas (RAMALHO E OLIVEIRA, 2005) exigem letramentos específicos. O corpo docente das demais áreas conseguiu estabelecer relações para além do caráter ilustrativo e em alguns casos estéticos e experimentais. Daí a importância da formação específica do professor de cada linguagem artística para atuar em todos os níveis da educação básica. Essa questão ficou evidente quando os professores de Barcelona, já no primeiro encontro, solicitaram a participação da professora de artes visuais para atuar ativamente no projeto; eles verbalizaram com avidez a relevância de sua presença como docente especialista da área para realizar a mediação junto aos estudantes.

Ao final desta experiência na escola Mossèn Jacint Verdaguer, os alunos e os docentes prepararam uma surpresa para a professora brasileira, um arquivo com desenhos das crianças, em que elas retrataram visualmente sua participação nas aulas. Alguns desenhos eram agradecimentos, outros enfatizavam 0 caráter estrangeiro da pesquisadora, aviões, malas e praias brasileiras apareceram em seus traços.
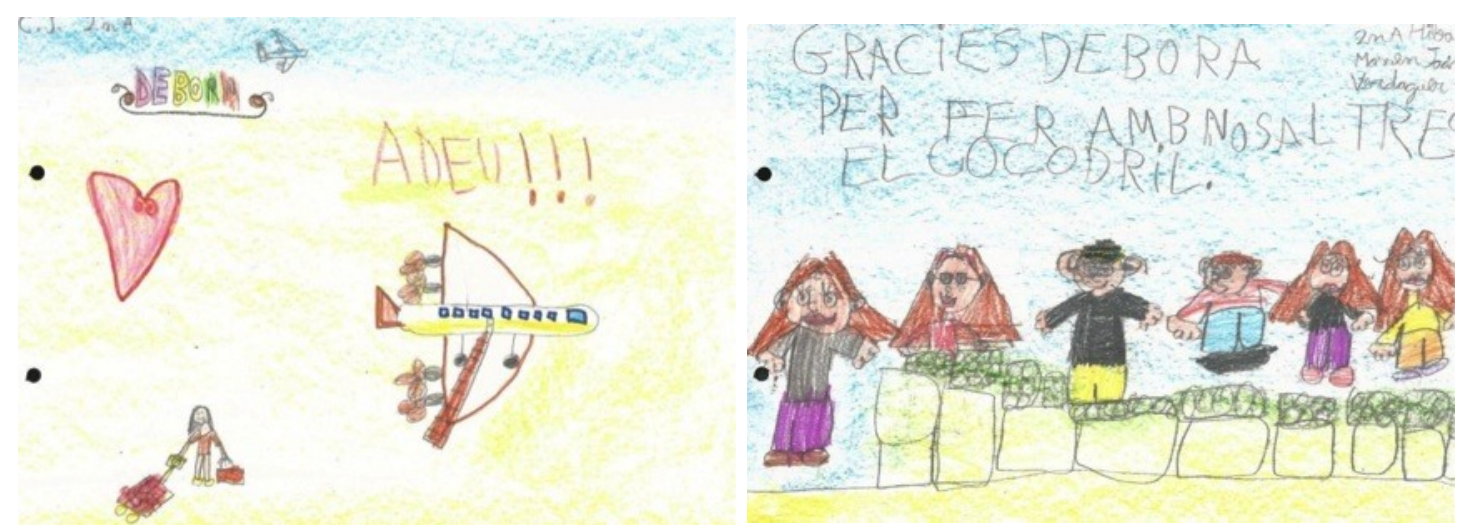

Fig. 14 - Desenhos em que se evidencia o caráter estrangeiro da professora de Arte.

Por outro lado, cenas que vivenciaram juntos também foram recorrentes. Em vários desenhos, a professora brasileira aparecia atuando ao lado das professoras regentes e das próprias crianças, enfatizando o trabalho coletivo. Essa narrativa 
visual se tornou evidência para a pesquisa, mesmo não sendo previamente planejada, converteu-se em dado importante para compreender como a presença da professora de Arte foi interpretada pelas crianças, ora como uma estrangeira que deixava saudades, ora como uma professora especialista que trabalhava conjuntamente em sala de aula. Não se identificou em nenhum momento o caráter de pesquisadora/observadora do contexto, devido à atuação participativa. Convém ressaltar que se estabeleceram com os estudantes laços afetivos, no dia da despedida, abraços coletivos, beijinhos e pedidos de que voltasse foram manifestações que ocorreram em todas as turmas. A ideia estereotipada de que as crianças de educação europeia mantinham certo distanciamento afetivo, se comparadas com as crianças brasileiras, não foram observadas, pelo contrário foram bastante carinhosas e próximas desde o primeiro encontro.

\section{A POÉTICA DAS VÉRTEBRAS}

Devido ao curto período de tempo de intervenção no Projeto Tándem da Escola Mossèn Jacint Verdaguer, optou-se por enfatizar neste campo um dos três objetivos específicos da pesquisa "IEBA na escola: arte como centro de narrativas investigativas", que versava sobre: construir narrativas de pesquisa que articule as imagens e as palavras no processo de escritura final de pesquisa. Apresentar os resultados da pesquisa usando recursos das linguagens artísticas é uma das questões características das pesquisas educativas baseada nas artes (PEBA), ampliando a divulgação do conhecimento científico para além dos muros da academia.

Dessa forma, o propósito do informe final seria relatar essa experiência em Barcelona rumo a um duplo destino: aos professores no Brasil e aos professores na Espanha. Portanto, a partir daqui o texto deste artigo passa a voz narradora em primeira pessoa da professora de Arte brasileira. Assim, busca construir um relato de experiência como um bricoleur (KINCHELOE e BERRY, 2007), em que cada escolha visual é descrita com riqueza de detalhes, pois de acordo com as metodologias artísticas de pesquisa, deve-se construir um discurso no qual estejam explicitadas as relações entre os efeitos de sentido presentes nos dados da 
pesquisa, integrando as linguagens artísticas e a linguagem verbal, num texto em que o visual não seja apenas uma ilustração do verbal.

\subsection{A LÍNGUA NÃO TEM OSSO: A VOZ DA VIAJANTE}

Sou a professora de Arte que viveu uma experiência educativa compartilhada com professoras regentes em Barcelona. Para escrever o relatório final da pesquisa a primeira ideia que tive foi tentar demonstrar como senti falta de ter vivido o final do processo, contribuindo na construção narrativa do musical que buscava contar o que as crianças aprenderam durante o ano letivo de 2014-2015, pois essa proposta, em meu diagnóstico, era o link potencial para usar as artes, visual e sonora, como linguagem em sua essência semi-simbólica. Mas como eu poderia representar esse potencial, tanto para os professores da escola Mossèn Jacint Verdaguer quanto para os docentes do Colégio de Aplicação da UFSC? Pensei nas aulas que vivi nesses quatro anos em que venho trabalhando de forma interdisciplinar com minhas colegas do Teatro nos primeiros anos do Ensino Fundamental no CA-UFSC, de forma mais específica no espetáculo que construímos conjuntamente com os alunos dos quintos anos, também num projeto interdisciplinar em Arte no ano de 2014. Tais experiências me inspiraram a buscar incorporar simbolicamente a linguagem cênica como recurso propositivo de manipulação e reconstrução narrativa. Dessa forma, construí uma espécie de teatro de marionetes em miniatura, apropriando-me das esculturas produzidas pelas crianças em Barcelona como figuras a serem manipuladas. A estrutura é simples, uma caixinha de papel kraft com tampa transparente, ao fundo um cenário construído apenas com superfícies de cor para realçar as silhuetas dos personagens. A tampa da caixa é transparente para dar luminosidade ao cenário. Na parte superior da caixa encontram-se aberturas no sentido horizontal que apoiam botões em forma de mãos indicando que os animais, presos por fios de nylon podem ser facilmente manipulados. É a proposta de que o leitor, assim como a pesquisadora, mesmo que não tenha vivido o momento final desse relato, possa interagir com o cenário e propor sua própria narrativa a partir dos animais vertebrados tridimensionais, produzidos pelos estudantes dos Anos Iniciais, representados em fotografias bidimensionais. 
Blumenau, v.14, n.1, p.169-192, jan./abr. 2019

DOI: http://dx.doi.org/10.7867/1809-0354.2019v14n1p169-192
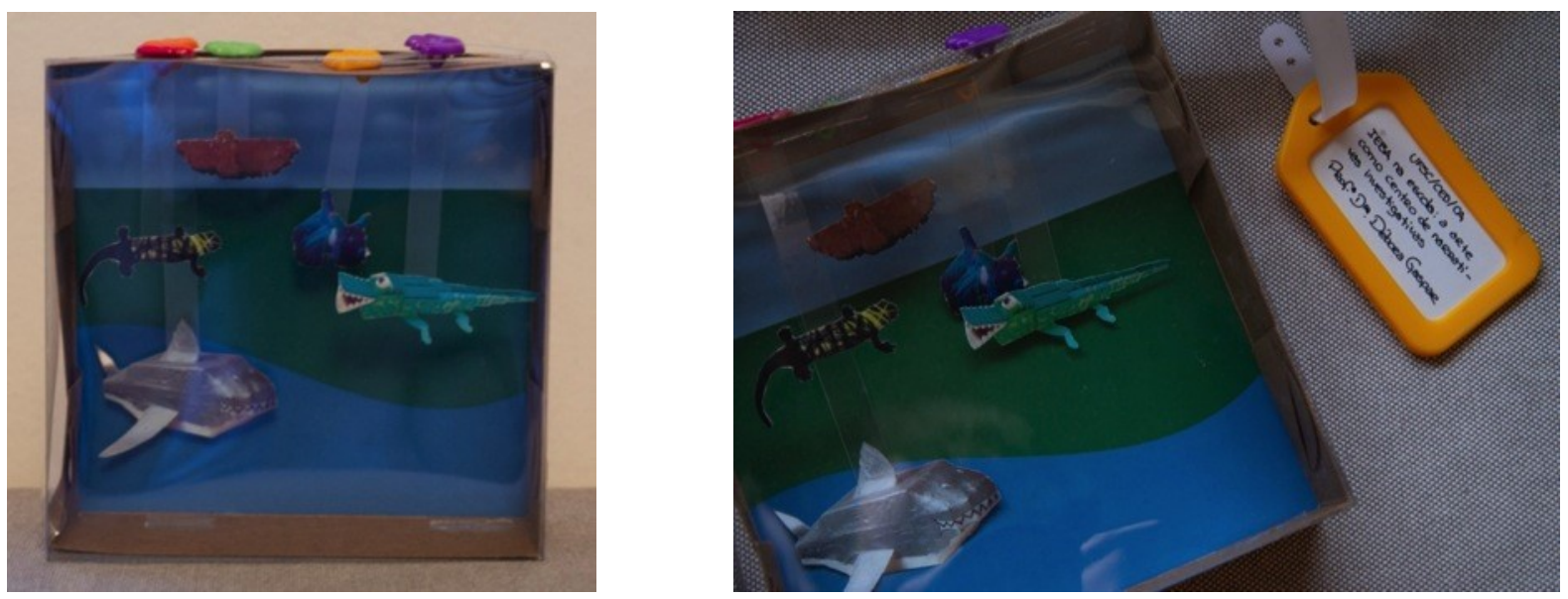

Fig. 15 e 16 - Foto do teatro de marionetes.

Para mostrar visualmente do que tratava o projeto, fiz um pequeno livro sanfonado, em que as páginas são divididas em dois eixos narrativos. Em um lado estão as letras das canções, tema que gerou os animais a serem representados pelos estudantes, as figuras dos animais produzidas pelas crianças e um código QR do mp3 com a música; entretanto, no último momento resolvi retirar o código, pois não tinha como criar com código sem publicar as vozes das crianças, assim suprimi este recurso em respeito ao anonimato dos alunos. Na outra parte da página encontra-se um mosaico de fotos do processo que deu "corpo" aos animais plásticos. $O$ tamanho reduzido das imagens e filtros, faz com que se possa observar a cena, mas não se reconheça a fisionomia dos estudantes, outro recurso para preservar o anonimato das crianças.

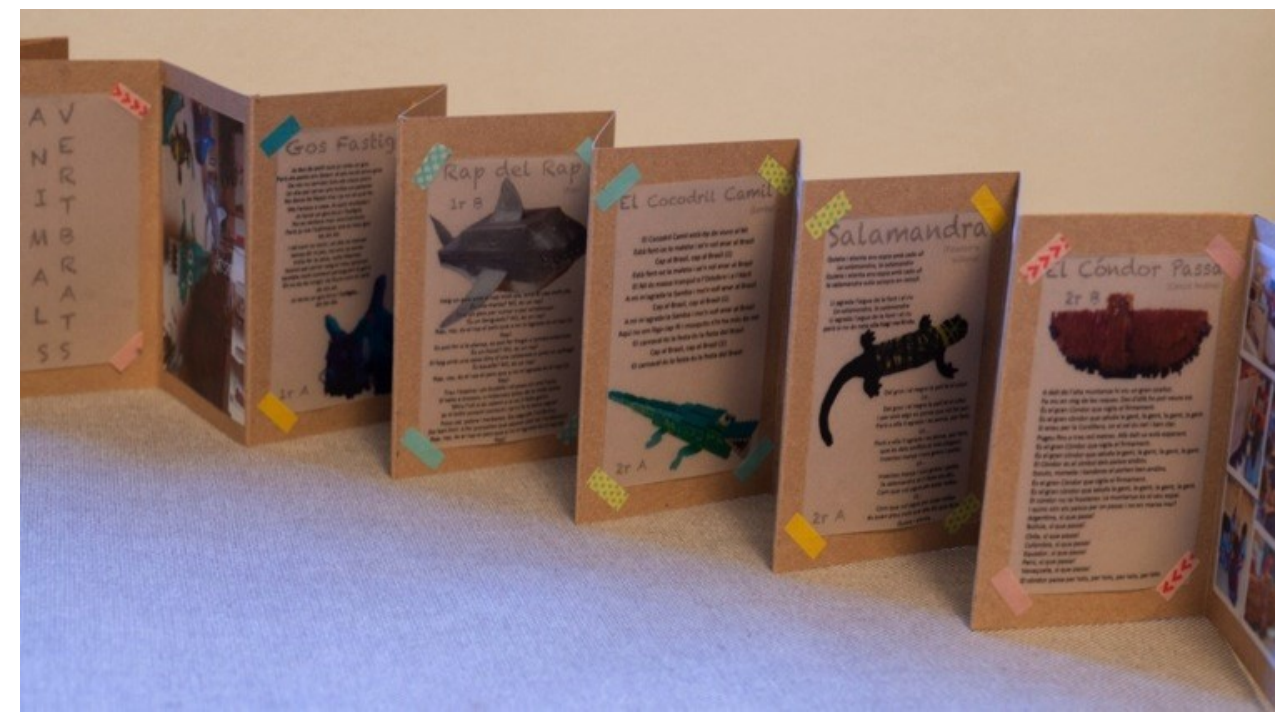


Fig. 17 - Livro sanfona com imagens e letras das músicas do Projeto Tándem 2014-15

Outro elemento narrativo é um envelope repleto de carimbos postais que guarda uma pequena garrafa de vidro com areia da praia de Itaguaçú em Florianópolis (SC, Brasil), pendurada em uma foto dos quatro educadores com os animais e que leva uma escritura individual de agradecimento à acolhida dos "maestros" de Barcelona. Tanto o livro sanfona como o envelope estão colocados dentro de uma caixa transparente, que remete a uma valise de viagem, validando o cuidado e a proteção dados a esses discursos pela pesquisadora.

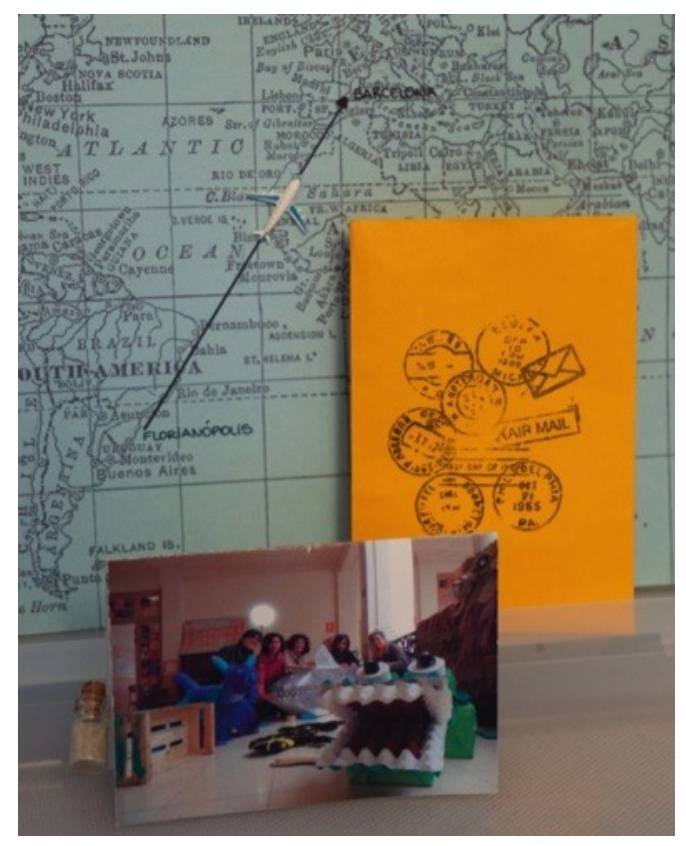

Fig. 18 - Cartão postal aos professores

Outro elemento do relato é o mapa-múndi de dupla face, indicando os pontos de chegada e partida: Florianópolis - Barcelona; Barcelona - Florianópolis. A flecha desenhada sobre o mapa em linha contínua remete à fluidez do caminho e à dimensão em pequena escala da distância de deslocamento, uma cartografia rudimentar complementada com um adesivo tridimensional na forma do avião, colada na metade do caminho traçado, que busca materializar o trajeto.

Roldan e Viadel (2017) ressaltam que os informes das metodologias artísticas de pesquisa devem ser permeados pela justificativa de cada elemento visual utilizado, de como foram articulados em seus procedimentos relacionais para gerar 
efeitos de sentido. Essa descrição detalhada é o que proporciona rigor acadêmico às narrativas artísticas de pesquisa, uma vez que as imagens ou demais textos semisímbólicos não são utilizados como mera ilustração, mas como elementos intrincados na tessitura do discurso sincrético dos informes das pesquisas baseadas nas artes. Dessa forma, o texto escrito, que fundamenta a pesquisa, vem impresso em tamanho A7 e envolto em uma capa plástica de cor amarela, para contrastar de forma harmônica com o tom turquesa do mapa, dando calidez e ao mesmo tempo sintonizando com o tom amarronzado do papel kraft utilizado na estrutura do cenário descrito anteriormente. Esta capa plástica é um objeto utilitário vendido em muitas lojas de souvenires para proteção de passaportes, por isso está impresso em letras douradas o substantivo PASSAPORTE. Esse elemento foi selecionado para remeter ainda mais ao fato de que o relato que se apresenta é uma visão estrangeira, viajante e peregrina.
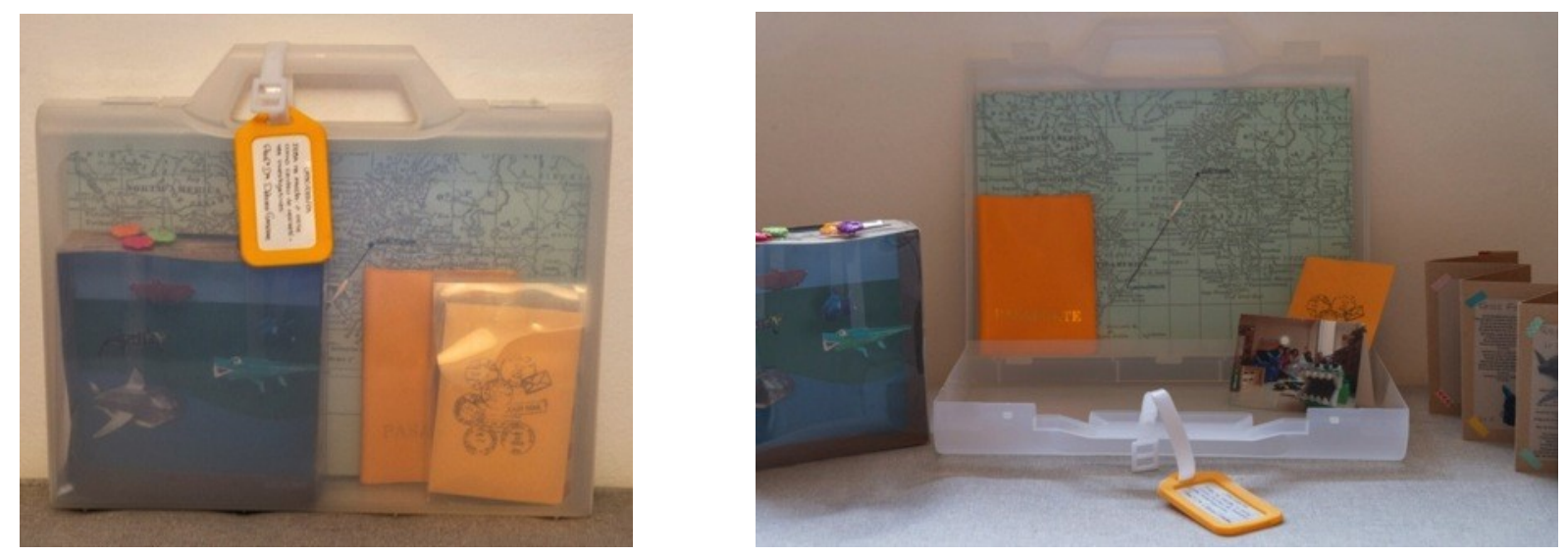

Fig. 19 e 20 - Mala com todos os elementos

Todos esses elementos estão envoltos por uma espécie de mala translúcida; mala é onde se guardam e transportam os objetos de viagem, as memórias e lembranças materializadas. Portanto, selecionar uma pasta pequena para guardar os objetos discursivos também é um elemento significante, porque mostra a dimensão da experiência que, mesmo breve, foi intensa. Já o fato do material da mala ser rígido indica certo cuidado ou proteção com os dados da vivência. Entretanto, a mala ser translúcida evidencia o desejo de compartilhamento, ao mostrar explicitamente os elementos que representam o que se viveu e aprendeu nessa viagem do conhecer e aprender com e sobre arte na escola. 
Os dados de identificação da pesquisa e autoria vieram pendurados pelo lado de fora da mala, numa espécie de fivela onde o nome do projeto, instituição a que se vincula e autoria vinham anexados à alça como nas malas encontradas em qualquer aeroporto do mundo, mais um elemento para reforçar o olhar estrangeiro da pesquisadora sobre o campo de intervenção da pesquisa.

Tal narrativa foi construída em quatro versões para ser entregue aos professores participantes da experiência, o olhar curioso e ao mesmo tempo surpreso para o objeto narrativo foi expresso pelos educadores no momento de interagirem com a maleta construída pela professora de Arte. Como exploradores foram abrindo a mala, a valise, o passaporte, olharam atentamente o mapa dos dois lados, manipularam e brincaram com o cenário, risos e comentários saudosos também foram identificados nesse comento de compartilhamento.

Mas essa mala viajou para além das territorialidades conhecidas e foi apresentada em uma palestra no Centro Cívic de Poble Séc, bairro em que está localizada a escola Mossèn Jacint Verdaguer em Barcelona. Assim, novos viajantes, encantados pelo relato, entraram nessa barca (símbolo da escola Verdaguer) para viajarem pelos conhecimentos em arte e educação que se poderiam desenvolver naquele lugar. Nesse evento, observei como um relato de experiência materializado a partir de linguagens artísticas causa uma aproximação maior de um público diverso, seja de especialistas, pais, ou pessoas de outras áreas. Assim, fascinadas pela embarcação das possibilidades artísticas na escola novos rumos foram vislumbrados para o projeto Tándem, abrangendo desde então uma nova tripulação composta também pelas educadoras da Fundação Joan Miró. 


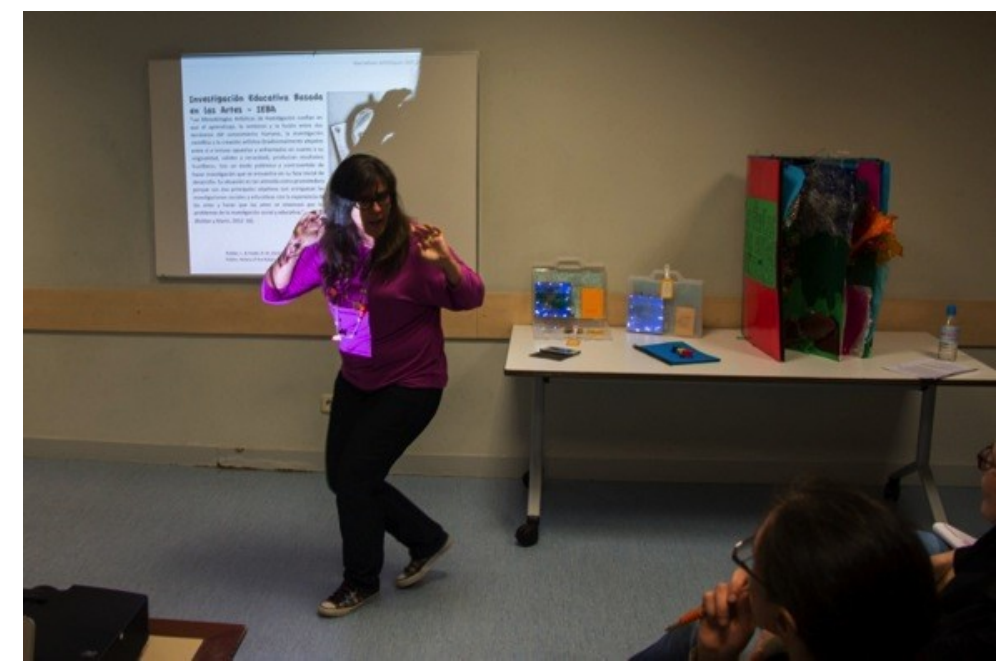

Fig. 21 - Palestra Centro Cívico "Sortidor”, Poble-sec/Barcelona, maio de 2016.

Um ano depois, fui convidada pela diretora da escola para participar do "claustro", reunião com os professores de toda a instituição para apresentar o relato viajante, pois o propósito da diretora era motivar os demais professores para que toda a escola trabalhasse por projetos. Propósito alcançado, hoje os projetos educativos se expandiram para além dos primeiros e segundos anos, iniciando novos rumos para o currículo escolar.

Constatou-se, assim, a efetividade de um discurso sobre a experiência educativa para além do caráter ilustrativo das imagens, uma vez que na maioria dos relatos os textos verbais são o centro das narrativas e os registros visuais são apropriados como forma de validar o discurso descritivo das palavras como ilustração estética. Observei o encantamento dos docentes pela narrativa apresentada, um relato que evidenciou as possíveis relações entre o professor específico de Arte e o "maestro" da turma, que devem navegar na mesma embarcação, sincronizando os remos para cruzar as marés do ensinar e aprender na escola. O olhar estrangeiro, enfatizado no livro sanfona, no passaporte, nos mapas e maleta, indicava de forma significativa que aquele relato forasteiro trazia na bagagem uma mescla de novas experiências impregnadas de suas referências de origem, na busca de desconstruir as territorialidades em fronteiras fluídas de sentidos e experiências compartilhadas.

\section{DÉBORA DA ROCHA GASPAR}


Doutora em "Artes y Educación" pela Universidad de Barcelona. Professora pesquisadora da Universidad de Girona (2018 / atual). Professora de Artes Visuais do Colégio de Aplicação da Universidade Federal de Santa Catarina (UFSC), atualmente em licença.

\section{SÍLVIA ÚBEDA PORTABELLA}

Professora dos Anos Iniciais, Inglês e Educação Infantil em instituições públicas de Educação Básica na Catalunha (Espanha). Atualmente atua como professora dos Anos Iniciais na Escola Mossèn Jacint Verguedar - Barcelona / España. Graduação em "Mestra d'Educació Especial" pela Universitat de Barcelona (2007-2010); Pósgraduada em Psicologia Clínica Infantil pela Fundació Eulàlia Torras Beà (20042005). Licenciada em Psicologia pela Universitat de Barcelona (1999-2003).

\section{MARÍA LUISA DE LA FUENTE MELENDRO}

Professora (aposentada) de Educação Infantil e Anos Iniciais em instituições públicas de Educação Básica na Catalunha (Espanha). "Mestra de primaria, especialista en educación infantil" e Licenciada en "Psicología, especialidad: clínica" pela Universidad Central de Barcelona.

\section{MARÍA LUISA ÁLVAREZ PÁEZ}

Professora dos Anos Iniciais em instituições públicas de Educação Básica na Catalunha (Espanha). Atualmente atua como professora da Escola Mossèn Jacint Verguedar - Barcelona / Espaha. Licenciada em "Filosofia i Cièncias de I'Educació" pela Universitat de Barcelona.

\section{REFERÊNCIAS}

BARONE, T., \& EISNER, E. Arts Based Research. California: SAGE, 2012, 208 p.

CONELLY, M. \& CLANDININ, J. (1995). "Relatos de Experiencia e Investigación Narrativa”. In: J. Larrosa, et alt. (1995). Déjame que te cuente. Ensayos sobre narrativa y educación. Barcelona: Laertes, 11-59 p.

HERNÁNDEZ, F. Espigadores de La cultura Visual: otra narrativa para la educación de las artes visuales. Barcelona: Octaedro, 2007,128p.

KINCHELOE, J.L. \& BERRY, KS. Pesquisa em educação: conceituando a bricolagem. Porto Alegre: Artemed, 2007, 208p.

RAMALHO E OLIVEIRA, S.R. Imagem também se lê. São Paulo: Rosari, 2005, $191 \mathrm{p}$.

ROLDÁN, J., \& VIADEL, R. M. Metodologías artísticas de Investigación en educación. Málaga: Aljibe, 2012, 276 p. 
Blumenau, v.14, n.1, p.169-192, jan./abr. 2019

DOI: http://dx.doi.org/10.7867/1809-0354.2019v14n1p169-192

ROLDÁN, J., \& VIADEL, R. M. Ideas Visuales. Investigación Basada en Artes e Investigación artística. Granada: EUG, 2017, 253 p. 